University of Montana

ScholarWorks at University of Montana

Summer 2006

\title{
Technology as a Cultural Force: For Alena and Griffin
}

\author{
Albert Borgmann \\ University of Montana-Missoula, albert.borgmann@umontana.edu
}

Follow this and additional works at: https://scholarworks.umt.edu/philosophy_pubs

Part of the Philosophy Commons

Let us know how access to this document benefits you.

\section{Recommended Citation}

Borgmann, Albert, "Technology as a Cultural Force: For Alena and Griffin" (2006). Philosophy Faculty

Publications. 17.

https://scholarworks.umt.edu/philosophy_pubs/17

This Article is brought to you for free and open access by the Philosophy at ScholarWorks at University of Montana. It has been accepted for inclusion in Philosophy Faculty Publications by an authorized administrator of ScholarWorks at University of Montana. For more information, please contact scholarworks@mso.umt.edu. 


\section{PROJECT MUSE}

\section{Technology as a Cultural Force: For Alena and Griffin}

Albert Borgmann

The Canadian Journal of Sociology, Volume 31, Number 3, Summer 2006, pp. 351-360 (Article)

Published by University of Toronto Press

DOI: $10.1353 /$ cjs.2006.0050

$\Rightarrow$ For additional information about this article

http://muse.jhu.edu/journals/cjs/summary/v031/31.3borgmann.html 


\title{
Note on Society/Réflexion sur la société
}

\author{
Technology as a Cultural Force \\ For Alena and Griffin
}

Albert Borgmann

To various degrees, the citizens of the advanced industrial countries are suffering from a crisis that is as profound as it is vague and therefore hard to deal with. The problem is particularly acute in the United States, however, and in what follows, some of the illustrations pertain particularly to that country, the one I live in and know best. In any case, though vagueness obscures the crisis, there have to be symptoms of some sort; otherwise we would not feel troubled. What are the signs of trouble in the culture of technology and democracy? First there are economic problems - national budget deficits, problems of international trade, newly emerging and powerful competition, viz., India, and China, and the dwindling supply of oil.

The last issue connects with the environmental worries. We could easily increase the supply of energy by burning coal and splitting atoms. The problem with the environment is not that it has run out as a source, but that it is overflowing as a sink. We don't know what to do with harmful emissions or how to store nuclear wastes. Hence global warming has become a looming threat. But pollution and species extinction remain problematic as well.

In the political sphere, we face foreign and domestic issues. There are people that bitterly hate the liberal democracies and terrorize them as best they can. There are also people around the globe who are in bitter need of aid. Domestically, the distance between the rich and the poor and between conservatives and liberals is wide and has been growing in some cases. The sense of national unity and cooperation is weakening. 
These are obvious and grave problems. But the problem with these problems is that we can solve them, and one gets the depressing feeling that even if they were solved, the deep and troubling malaise would remain. With the problems solved we might be in the position of the person who had ambitious goals and succeeded - the advanced degree, the appropriate spouse, the successful career, the children studying at elite universities, the retirement provided for, and still the sense of a life misspent.

The industrial democracies could address their budget woes and stimulate innovation, production, and export. They could stretch their energy resources through technological sophistication and conservation and push the advancement of clean energy. They could improve on the Kyoto protocol and embrace the Millennium project. They could make taxes more progressive and increase welfare spending. They could increase domestic security and pursue a foreign policy that would decrease the resentment of so many Muslims. They could do this without severe consequences to their standard of living, and they would certainly be better countries as a consequence, more stable, more secure, more just. But we, the citizens of these democracies, would still be in a position of the person who to all appearances did everything right and yet feels empty, forlorn, and aimless. The overt problems having been resolved or at least addressed, we might eat well, but we would not sleep well.

Something must be amiss in this analysis, however. If the signs of trouble in fact turn out to be overt problems that can be solved, where are the symptoms of the deeper troubles to begin with? There are, I believe, indicators in the economy, the environment, and politics that point to more profound issues. An economy whose prosperity has been set on a stable footing will fail to make us happy. An environment that is sustainable and benign will not give us a sense of belonging. And politics of social and global justice will leave us morally abandoned.

There are people who have recognized and are concerned with these issues. Social scientists have observed that our economy is not designed to help people pursue happiness successfully. The deepest concern of most environmentalists is not just to secure a sustainable setting for our way of life, but to bring about a wider and more meaningful way of life. Finally, there is a hunger for a moral vision that liberals are desperately trying to understand and conservatives warmly embrace but largely misunderstand.

Although these responses to the economy, the environment, and politics point to grave problems, they are themselves more like symptoms than diagnoses. All of them are partial, and many are confused. My suggestion is that for a proper understanding of our cultural malaise we have to get a grip on technology as a cultural force. But what is technology? In its narrow sense it is an ensemble of machineries and procedures. Take its most recent instance information technology. It's hardware and software, broadly conceived. On the 
hardware side there are chips, disks, screens, keyboards, and fiber optic cables. All this extends into the production machinery and farther back into power generating plants and silicate mines. The software is lines of code and extends on one side to the procedures of designers and programmers and on the other side to the procedures you follow to compose and send e-mail, to check on the New York Times on the Web, or to design a web page. We can call this the engineering sense of technology.

What interests social theorists is the effect that these machineries and procedures have had on our way of life. Social theorists are interested in technology as a cultural force. Technology in this sense is widely used in philosophy, the social sciences, and in the media to capture what is distinctive of contemporary culture. But there is no consensus on just what the cultural effect of technology is. There is a lot of inconsistency in the comments of scholars, journalists, and public figures, but most claims about the force of technology can be sorted into one of two standard views: the determinist view and the instrumentalist view.

The determinist view comes in two flavors, pessimistic and optimistic. In either case, technology is seen as an encompassing and irresistible force. If you are an optimistic determinist, you welcome the problems and the blessings of technology, and you will warn critics and opponents that you can't stop technology. Get with the program or become irrelevant. The pessimistic determinists have a more definitive and, not surprisingly, a darker view of technology. They see it as a culturally and environmentally destructive force, and they sometimes give a penetrating if one-sided view of the fundamental features of the technological culture.

The determinist view of technology is marginal, however, in the public conversation of this country. The optimists are casual in their pronouncement; the pessimists, though anything but casual, are readily rejected as Luddites, dystopian, romantics, or nostalgic sentimentalists. The official position everywhere is instrumentalist. Technology is neither good nor bad it is often said. It depends on us and our values whether it is used well or ill. Whenever politicians or business people are confronted with contentious issues of technological culture, they invoke the instrumentalist reading of technology.

The standard views are not without merit. The determinist position in its pessimistic version reveals grave problems that are usually swept under the rug. And there is obviously merit to the instrumentalist view. Such technological items as television and fast food have a legitimate and positive place in our culture when used judiciously, but they are harmful when used to excess. None the less, both positions suffer from serious defects as cultural interpretations of technology.

The determinist view for all its insights is essentially in error. Both individuals and society have a lot of discretion in adopting technological devices 
and procedures. Some people have no television; others refuse to eat fast food. Society, by way of its government, can refuse to build supersonic transport airplanes and decide to phase out nuclear power. To be sure, technology can no longer be rejected in its entirety. But its progress can be slowed and directed.

The instrumentalist view is undoubtedly correct at its avowed level of observation. But it ignores and tends to conceal a deeper level of cultural reality. It overlooks the technological version of what may be called Churchill's principle: "We shape technology; afterwards technology shapes us." Most people do have television and watch it for hours every day. Many people regularly eat fast food. Is this a mere accident? Is it the result of many millions of individuals rationally optimizing their welfare? Or is there something in the structure of the technological culture that conduces to television watching and fast food consumption?

The determinist answer is of course a definitive yes. But, it gives the wrong and in fact an inscrutable answer as to the conducive force of technology. What I propose as an alternative to both the determinist and instrumentalist positions we may call the paradigmatic view. The basic idea is simple. Technology is defined by a pattern or paradigm we have agreed to follow in dealing with reality. Two questions obviously follow from this definition. (1) What sort of agreement is this, and (2) what does the paradigm look like?

To answer the first question we need to observe first of all that there is an agreement. There is great uniformity across cultures and countries to the way societies industrialize and consume. Look at China. As it approaches the status of an advanced industrial society, it is becoming more and more like the United States or Germany. It is radically extending its system of roads, powerlines, communication links, water and sewage lines; it is building dams, factories, and high rise buildings. Its citizens are moving into the cities; they buy radios, television sets, computers, cell phones, and fast food.

So when did the Chinese agree to transform their world this way? Never explicitly. Nor did Germans or Americans. We can trace the precipitation of this agreement in the nineteenth century. But a crucial feature of the agreement is its implicitness, which ironically is the source of its power. The technological approach to reality rules as largely unchallenged common sense. It determines the course of events. This is the grain of truth in technological determinism. But we can and we should make the agreement explicit, evaluate it, and on due consideration embrace, reject, or modify it. Because we can do any of these three things, determinism is false.

Raising this collective agreement to explicitness is of course a sort of clarification, and it therefore converges with the chief problem that concerns us to illuminate the deep and vague malaise that is plaguing us. But a successful illumination obviously depends on a good answer to the second question: What does the paradigm look like that we have agreed on? 
It's best to back into an answer by way of a common phenomenon in contemporary culture, the enjoyment of music. Imagine that your spouse tells you that the local symphony orchestra will give a performance two weeks hence. They will play among other pieces Beethoven's pastoral symphony, your favorite. You have a nice dinner before, walk to the hall. It's early summer, a thunderstorm is gathering. You enter the hall. It's one of the resplendent theaters from the times when going to the movies was an important communal affair.

The orchestra is composed of accomplished amateurs. You know at least a third of them. It's a brave and enjoyable performance. You step out of the building. The thunderstorm has passed. It feels fresh and serene out there just as in the fifth movement of Beethoven's symphony.

But now imagine that the treat of lightning and rain, the trouble of getting ready for the concert, and the prospect of a mediocre performance make you decide to stay at home and listen to a $\mathrm{CD}$ of the symphony. You have four renditions to choose from, the Berlin Philharmonic with Karajan, the Vienna Philharmonic with Furtwängler, the Royal Philharmonic with Weingarten, and the Vienna Philharmonic with Bernstein. You're in a contemplative mood and go with Furtwängler. The digitally remastered disk is technically astonishing and emotionally moving.

It's Beethoven's symphony either way, we tend to think, though there is of course a difference in artistic quality. Your civic symphony can't compete with Furtwängler and the Vienna Philharmonic. But to think so is to overlook the crucial difference between actual and recorded music. There is a liberty and prosperity to recorded music that actual music cannot hope to match. A fine stereo system liberated you from the confinements of a particular time and place, the annoyances of coughing and undiscriminating fellow listeners, the embarrassments of amateur performances. A fine collection of CD's puts the best renditions of all times and places at your disposal in superb acoustic quality.

This kind of liberty and prosperity is characteristic of the technological culture. Liberation is more prominent in areas such as health and safety. We are free of the threat of dying from diphtheria or tuberculosis. We can confidently expect to live into our eighties. Starvation won't knock on our door, and there is no danger of our freezing to death. Richness rules our enjoyment of food, information, and entertainment. You can have oranges from distant places, lettuce in winter, and exotic dishes from anywhere. If you are curious about life in your hometown or the fall of Rome, Google will get you the information. Any evening you can watch any of hundreds of movies from the comfort of your couch.

How are these freedoms and riches possible? They are delivered by powerful and sophisticated machineries. The Furtwängler edition of Beethoven's sixth comes from a compact disk whose digital content is read by a laser, amplified 
and smoothed out by transistors, and converted into sound by speakers. Underneath this machinery sits the electrical utility, the transportation system, the CD factory, the recording studios, and more. The power of this machinery is due to scientific insight and engineering ingenuity. Its growth is due to the energy of capitalism. The power and size of this machinery make the riches of technology available. Availability is the way these goods are present to us. They are at our disposal instantly, everywhere, easily and safely. We can capture the comfort and commodiousness of these goods by calling them commodities.

We now have the outline of the technological pattern or paradigm before us. It is well-instantiated by a technological device such as a stereo system and is composed of two parts: the machinery and the commodity that is produced by the machinery, a CD player, amplifier, and speakers that deliver music. We can call this the device paradigm of technology, and we can think of the history of this country as the gigantic enterprise of transforming the world according to this pattern - putting in place vast and complex machineries that produce an unencumbered richness of commodities.

That history has its obvious grandeur and undeniable success. So how could it lead to our present uneasiness and uncertainty? The answer is, I want to suggest, that the rule of the device paradigm is inherently unable to provide what we expect from the economy, the environment, and politics. And what are those expectations? Broadly speaking we expect a sense of well-being from the economy, a sense of belonging from the environment, and a sense of common purpose from politics.

The promise of well-being has powerful and genuine appeal when there is misery and deprivation and especially when these evils become removable as they did in the early nineteenth century. The prospect of relief and comfort has led to incredible and successful exertions over a century and a half. But imperceptibly and yet consistently, the efforts of industry and technology have more and more shifted the balance from relief to pleasure. Most important, the emerging kind of pleasure has been defined and informed by technology.

It's a commonplace that pleasures are found in leisure and consumption and that labor and production are for most of us merely the means to the end of pleasure. This division of means and ends reflects the pattern of technology, i.e., the device paradigm and its division and conjunction of machinery and commodity, and it gives technological pleasures a peculiar purity and intensity. The pleasures we enjoy in consumption are purified of all exertions and obligations. The great variety, moreover, in which they are available, makes it possible to pick those commodities that please my tastes most fully.

Imagine a teenager in the 1940's who is a desperately devoted Sinatra fan. To catch just one of his songs she has to listen to the radio for hours - a difficult task since she does not have a radio of her own. Going to a Sinatra 
concert is out of the question. But whenever she hears that sinewy voice and that artful phrasing, she is transfixed.

Now consider an unusual teenager in 2006 who discovers Sinatra on some compact disk. He listens to it at home in his boom box, on the CD player in his car, and on his iPod while walking around. He orders another CD from Amazon.com, and then another. He gets all the Sinatra CD's. His sonic world is wall-to-wall Sinatra. The fan of the forties would have deeply envied the fan of 2005. What would she have given for the quality, the variety, the ubiquity of the Sinatra recordings. And yet the teenager of 2005 is getting bored with Sinatra. He has discovered Bob Dylan. But Dylan is getting old too.

What he has run into, but failed to uncover as has our society in general, is the fickleness of technological pleasures. It is plausible to think that the most desirable pleasures are those that are free of preparation, of exertion, and of obligation. A commodity in the sense that I am using the term, answers this description perfectly. The supporting machinery has detached the commodity from all ties to circumstances and engagements. We have paid our dues to the harshness of reality in our work. In our leisure we want to consume the fruits of our labors freely and abundantly.

The force of the pleasures of consumption declines rapidly. A cold beer tastes best at the start. By the end of the bottle, I take it for granted, and after half an hour, the pleasure is gone. It declines more slowly over the long term, but it does so more harmfully. After a month of a bottle of beer every evening, it takes two bottles of beer every evening to get the old thrill. Addiction is the most severe case of the evaporation of pleasures.

A milder version of enthrallment harries consumption of commodities in general. It manifests itself in the cycle of excitement at the prospect of a purchase, the moment of exhilaration when you take possession, the decline of enjoyment, the sense of emptiness, the contemplation of another purchase, rising expectation, and so on. Everything in our economy is geared toward keeping the cycle strong. Yet underneath that cycle of ups and downs is an inarticulate sense of disappointment and failure.

What the device paradigm then helps us to see is why the pursuit of wellbeing as the pleasure of consumption is plausible, but also why that pursuit leads to disappointment and depression. The pleasures of commodities fail to keep their promise. They lure us to ever renewed efforts, but they leave us unfulfilled and betrayed. And thus we begin to see the epidemic of depression and anxiety that is gripping our society as a symptom of the deep-seated malaise I began with.

Meanwhile, the powerful machinery of technology has transformed the environment. There are the overt problems of global warming, pollution and energy shortage. But we could turn and have turned the power of technology on the 
problems it has created. Technology can be self-righting, and I think it will be though at terrible intermediate costs to humans and nature. So the perils of technology are not the deep problem.

What is profoundly disquieting and has robbed us of a secure sense of belonging is the fact that we are no longer embraced by nature, but rather, by conquering it entirely, have come to embrace all of nature. We are no longer the children of Mother Earth; rather Earth has become our ward. Humanity is now in the position of middle-aged persons who have seen their parents decline and are beginning to realize that there is no longer anyone to whom to look for guidance and support. There is no parental home anywhere to find rest and solace. You are in charge now, and it's an unsettling feeling. Our sense of homelessness is aggravated by the dissolution of a moral cosmology. Astrophysics is in a most creative and interesting phase. But it is silent on the meaning of it all.

Here again, we can see how the device paradigm of technology provided both an attractive blueprint for dealing with nature, but has also turned technological success into a moral calamity. And here too we can now see symptoms of a profound predicament. One is the understandable attempt to reinstall a moral authority in the natural world through creationism and the claim of intelligent design. But for all their plausibility, these attempts fail to see that human piety needs to be interwoven in a new way with human responsibility for nature and for what we know about it. Another symptom of our cosmic lostness is our aimlessness in dealing with nature, even when we are wellintentioned. Are we to restore it to pre-Columbian standards, convert it into one big, clean, and sustainable Disney World, or what?

What, finally, has been the cultural effect of technology on politics? This country and the way it has governed have drawn its purpose and energy from the transformation of this continent. Its dark side has been the grave injuries to Native American cultures and nations. At the same time it was a heroic and astounding enterprise. It began as the hand-to-hand struggle with the trees, the rocks, the soil, and the weather. It gained momentum through industry, steam engines, blast furnaces, railways, and factories. It redoubled its force once more when scientific research and technological development added sophistication to brute force. The emerging pattern of the conquest of nature showed the conjunction of mechanization and commodification that is characteristic of the device paradigm and in time has produced incomparable affluence.

The path to prosperity was not smooth and straight. There were times when dissent threatened the union, economic crises put the very feasibility of capitalist technology into question, and totalitarian regimes threatened the nation. But technological progress and broad prosperity were the lode stars that ever and again allowed the United States to regain its bearing. The national dedication to the progress of technology was congenial to the prevailing liberal democratic 
conception of what a nation or a state should be. It should not be, as some European thinkers and statesmen have thought, the embodiment of a moral ideal or a religious tradition, or of an ethnic destiny. Rather it should restrict itself to providing a secure and tolerant foundation for individual conceptions of the good life.

A country that is dedicated to the production of an abundant variety of styles of consumption seems to fit the liberal democratic idea of the state. But in fact a country patterned by the division of labor and leisure, of machinery and commodity, and devoted to the pleasures of consumption, has committed itself to a very definite and narrow conception of the good life. The journey toward that goal was hard, but it was also absorbing and energizing. On arrival at the goal, however, its pleasures have turned out to be neither fulfilling nor ennobling. Hence politics since the death of President Kennedy has been haunted by a sense of ethical emptiness.

The conclusion of the diagnosis of politics is that the device paradigm served us well as a source of vigor and cooperation. But the moral force of the paradigm is spent, and the evidence of this decline is the silence of the large and moderate middle population of this country. We have come to think of our society as deeply divided. But few people are extreme liberals or conservatives, and the broad middle, bereft of a common moral vision, has left the stage to the extremists.

Yet neither the liberal call for greater social justice nor the conservative call for traditional values has been able to address the moral malnourishment we, as a nation, have been suffering from. The reason is that neither party has been willing to recognize and question technology as a cultural force. Distributing the fruits of technology more evenly or layering values on top of technology will do nothing as long as technology structures the economy to produce disappointment, transforms the environment to yield homelessness, and thinks of politics in a way that leaves us with moral vacuity.

What does it mean to take on technology as a cultural force? Just upstream of Missoula, Montana, there is a dam for electricity generation, and behind it lies this country's greatest superfund site. Millions of cubic yards of toxic sediments had washed down from smelting operations near Butte. During the campaign to remove the sediments and the dam, bumper stickers began to appear that said: Remove the Dam, Restore the River. Soon you could see the opponents of the dam removal sport bumper stickers that replied: Remove Missoula, Restore the Valley.

The reform of technology is like the restoration of a river, not like the removal of a city. We can not and should not want to dismantle the technological devices that have produced and continue to support the blessings of health, education, and mobility. But these constitute the circumstances and not the center of the good life. At the center of our lives we have to remove the consump- 
tion of commodities and recover the presence of things that can engage the fullness of our capacities and center our communal life.

Once the sediments and the dam have been removed, trails and parks will extend upriver from Missoula. Walkers, runners, and bikers will meet one another. There will be more fishing and rafting, and there will be a stretch of white water to test kayakers. The Clark Fork will be even more of a focal thing for Missoula and a place for communal celebration.

At the smaller scale of the family - any group of two or more people who have cast their lot together - we need to rediscover as well what kinds of things and practices can provide us with a sense of orientation and shared belonging. The dinner table and the practice of regular common meals are perhaps the most important focal thing and focal practice.

In conclusion, then, what the device paradigm can teach us to see is its fruitful counterpart and an economy, environmental policies, and a politics that will serve that counterpart. We need to modify the economy so it is not overwhelmingly geared toward consumption, but invites engagement in focal things and practices and favors the acquisition and practice of virtues at least as well. We can begin to take constructive responsibility for the environment when we come to see it as a place of focal significance that we must create as much as recover. And politics needs to become both more single-minded in making room for communal celebration and more deeply pluralist in supporting the richness of cultures that is being swamped by commodification and consumption. When pleasures are thus embedded in engagement and celebration, they will not betray us. 